The Egyptian Journal of Hospital Medicine (April 2019) Vol. 75 (1), Page 1982-1986

\title{
Assessment and Management of Asymptomatic Bacteriuria in Pregnancy
}

Amany A. Soliman' ${ }^{1}$, Adel S. Hussein ${ }^{1}$, Ahmed G. Ahmed ${ }^{2}$

*Urology Department of Urology, ${ }^{1} \mathrm{Al}$-Azhar Faculty of Medicine and ${ }^{2}$ Cairo Fatemic Hospital, Cairo, Egypt

Corresponding author: Amany A. Soliman, Mobile: (+20)01006200471, E-Mail: damanyahmed@gmail.com

\begin{abstract}
Background: Asymptomatic bacteriuria in pregnancy is defined as the presence of a significant amount of bacterial growth in a urine culture taken from a urine sample and the absence of symptoms of urinary infection such as pain or urgency.Asymptomatic urinary tract infection is an important risk factor for developing acute symptomatic infection later in pregnancy, and it was also associated with a preterm labor, intra-uterine growth retardation and low birth weight infants.
\end{abstract}

Objective: This prospective study was aimed to assess the incidence, causative organisms, response to medication and follow-up for recurrence of asymptomatic bacteriuria in pregnant and non-pregnant women in a randomized pattern with maximum safety procedures to both mother and fetus.

Patient and Methods: This study included 100 pregnant and 50 non-pregnant women were screened for the prevalence of asymptomatic bacteriuria from March 2016 to May 2017 at AL-Zahraa University Hospital and Cairo Fatemic Hospital. All the subjects were clinically identified to have no signs and symptoms of urinary tract infection. The age ranges of the study and control groups were between 18-30 years. All were subjected to bacteriological screening of mid-stream (MSU).

Results: Revealed that 4/100(14\%) and 6/50(12\%) were positive for asymptomatic bacteriuria in the study and control groups respectively. The most prevalent organism was the E. coli $(71.4 \%, 83.3 \%)$ in both groups respectively.

Conclusion: All pregnant women should be screened for bacteriuria and subsequently treated with appropriate antibiotic therapy. Acute cystitis and pyelonephritis should be aggressively treated during pregnancy.

Keywords: Asymptomatic bacteriuria- culture and sensitivity- urinary tract infection.

\section{INTRODUCTION}

Urinary tract infections (UTI) affects all age groups, but women are more likely than men because of due to short urethra, pregnancy, easy urinary tract infections with fecal plants and many other reasons. Urinary tract infection is a common problem in pregnancy due to the morphological and physiological changes that occur in the genitourinary tract during pregnancy. It is of two types, symptomatic or asymptomatic ${ }^{(1)}$. Asymptomatic bacteriuria (ASB) is define as the "presence of actively multiplying bacteria within the urinary tract excluding the distal urethra", at a time when the patient has no urinary symptoms ${ }^{(2)}$. There are a number of conditions associated with an increased prevalence of asymptomatic bacteriuria in pregnancy: low socioeconomic status, sickle cell traits, diabetes mellitus and grand multiparity have been reported; each is associated with two-fold increase in the rate of bacteriuria ${ }^{(1)}$. Asymptomatic bacteriuria are found in $2 \%$ to $10 \%$ of pregnant women and are likely to develop acute pyelonephritis, postpartum UTI, hypertensive disease, anemia, prematurity, low birth weight babies if untreated ${ }^{(2-3)} .40 \%$ of asymptomatic bacteriuria cases develop into acute symptomatic UTI. Hence early detection and treatment is of considerable importance not only to forestall acute pyelonephritis and chronic renal failure in the mother, but also to reduce prematurity and fetal mortality in the offspring ${ }^{(4)}$. Asymptomatic bacteriuria is a microbial diagnosis based on the isolation of a specified quantitative count of bacteria in a properly collected specimen of urine from pregnant women without signs or symptoms of UTI.Thus urine culture is the gold standard screening technique for asymptomatic bacteriuria during pregnancy ${ }^{(4-5)}$.

The current study was aimed to assess the incidence, causative organisms, response to medication and follow-up for recurrence of asymptomatic bacteriuria in pregnant and non-pregnant women in a randomized pattern with maximum safety procedures to both mother and fetus.

\section{PATIENTS AND METHODS}

This prospective study included a total of 150 asymptomatic patients attending the AL-Zahraa University Hospital and Cairo Fatemic Hospital seeking medication for complaints other than urinary disease. Of them 100 primipara pregnant women at any trimester attending the ante-natal clinic and 50 agematched non-pregnant women attending medical outpatient department. Approval of the ethical committee and a written informed consent from all the subjects were obtained. This study was conducted between March 2016 to May 2017. The age of the study and control groups ranged from 18-30 years.

Exclusion criteria included history of severe UTI symptoms (dysuria and urgency), Pregnancy induced Diabetes Mellitus \& Hypertension, Hypertension, Diabetes mellitus, History of antibiotic therapy in the previous two weeks, Pyrexia, Vulvovaginitis and Known congenital anomalies of the urinary tract. 
All patients were subjected to complete blood count (CBC), ESR, CRP, Urine Analysis and Urine Culture \& sensitivity. All females (pregnant and nonpregnant) who had asymptomatic bacteriuria were given five days course of antibiotic according to culture and sensitivity test. Urine analysis, urine culture and sensitivity tests were repeated after treatment course to assess the recovery and after one month to assess the recurrence.

Specimen collection and transport: Clean catch midstream urine was collected from each patient into a sterile universal container following appropriate instructions to ensure the samples were free of contamination. Samples were transported to Lab within 2 hours in order to avoid bacterial multiplication. Refrigeration was not necessary as it might cause precipitation of phosphate and urate crystals.

Sample processing: Using a sterile centrifuge tube, approximately $10 \mathrm{ml}$ of each well-mixed, urine sample was centrifuged at $3000 \mathrm{rpm}$ for 10 minutes. After discarding the supernatant, a drop of a properly mixed deposit was microscopically examined at $10 x$ and 40x magnifications to detect the presence of pus cells, red blood cells, epithelial cells, casts, crystals, yeast-like cells, and Trichomonas vaginalis. Samples were cultured on 5\% Sheep blood agar (BA) and MacConkey Agar (MAC), using a calibrated drop delivering $0.002 \mathrm{ml}$ of urine. Incubation of plates was carried out in a $35^{\circ} \mathrm{C}$ air incubator after placing labels on each plate. Samples were visualized after 24 hours, if no growth 24 hours incubation was done. After that (sum of 48 hours) no growth meant negative sample. Colony count was done by naked eye and actual number of colonies was calculated by this formula $=$ colony count x 100/1 Ox dilution used.Colony count more than $10^{5} \mathrm{CFU} / \mathrm{ml}$ was considered positive for asymptomatic bacteriuria. Colony count $10^{3}-10^{4} \mathrm{CFU}$ $/ \mathrm{ml}$ was considered suspected infection. Colony count less than $10^{3} \mathrm{CFU} / \mathrm{ml}$ were considered contamination.

Antibiotic sensitivity test: Organisms showing significant bacteriuria were inoculated into peptone water before plating on Mueller-Hinton agar.
Commercially organized antimicrobial discs of known minimum inhibitory concentrations (MICs) were placed over the surface of the sensitivity agar and pressed down with sterile forceps to make enough contact with the agar.The plates were incubated at 37C for 24 hours and the zones of growth inhibition were estimated.[6] The antimicrobial sensitivity discs used were: Imipenem, Cefoperazone, Nitrofurantoin, gentamycin, Kanamycin, cephalexin and Amoxicillinclavulanic acid. Interpretation of results was done using the interpretation charts into: resistant (infection with this pathogen was with no response to treatment), intermediate (infection with this pathogen was with response to treatment in larger dose) and sensitive (infection with this pathogen was with response to treatment).

\section{Statistical analysis}

Data were statistically described in terms of mean \pm standard deviation ( \pm SD), and range, or frequencies (number of cases) and percentages when appropriate. Comparison between the study groups was done using Chi square $\left(\chi^{2}\right)$ test. Fisher Exact test was used instead when the expected frequency is less than 5. $p$ values less than 0.05 was considered statistically significant. All statistical calculations were done using computer programs SPSS (Statistical Package for the Social Science; SPSS Inc., Chicago, IL, USA) version 15 for Microsoft Windows.

\section{RESULTS}

In this study 14 cases of 100 pregnant women and 6 cases of 50 non-pregnant women had significant bacteriuria giving a prevalence rate $14 \% \& 12 \%$ in both groups respectively. The most frequent bacteria between the isolates was Escherichia coli (71.4\%) and (83\%) among infected pregnant and non-pregnant cases respectively, followed by Klebsiella $(21.4 \%)$ \& $(17 \%)$ in both groups respectively, while the least organism was staph aureus (7.2\%) among infected pregnant cases only.

Table (1): prevalence of pathogenic bacteria in urine samples of pregnant\& non-pregnant women

\begin{tabular}{|c|c|c|c|c|c|c|}
\hline \multirow[b]{2}{*}{$\%$ of isolates } & \multicolumn{3}{|c|}{ Pregnant } & \multicolumn{3}{|c|}{ Non-pregnant } \\
\hline & $\begin{array}{l}\text { No. of } \\
\text { isolates }\end{array}$ & $\begin{array}{l}\text { \% of } \\
\text { isolates }\end{array}$ & $\begin{array}{l}\text { Prevalence } \\
\text { rate \% }\end{array}$ & $\begin{array}{l}\text { No. of } \\
\text { isolates }\end{array}$ & $\begin{array}{l}\text { \% of } \\
\text { isolates }\end{array}$ & $\begin{array}{l}\text { Prevalence } \\
\text { rate \% }\end{array}$ \\
\hline E. Coli & $10 / 14$ & $(71.4 \%)$ & $10 \%$ & $5 / 6$ & $(83.3 \%)$ & $10 \%$ \\
\hline Klebsiella & $3 / 14$ & $(21.4 \%)$ & $3 \%$ & $1 / 6$ & $(16.7 \%)$ & $2 \%$ \\
\hline Staph aureus & $1 / 14$ & $(7.2 \%)$ & $1 \%$ & 0 & 0 & 0 \\
\hline Pseudomonas & 0 & 0 & 0 & 0 & 0 & 0 \\
\hline Proteus mirabilis & 0 & 0 & 0 & 0 & 0 & 0 \\
\hline Staph, epidermidis & 0 & 0 & 0 & 0 & 0 & 0 \\
\hline Staph. Saprophyticus & 0 & 0 & 0 & 0 & 0 & 0 \\
\hline Total & 14 & $100 \%$ & $14 \%$ & 6 & $100 \%$ & $12 \%$ \\
\hline
\end{tabular}




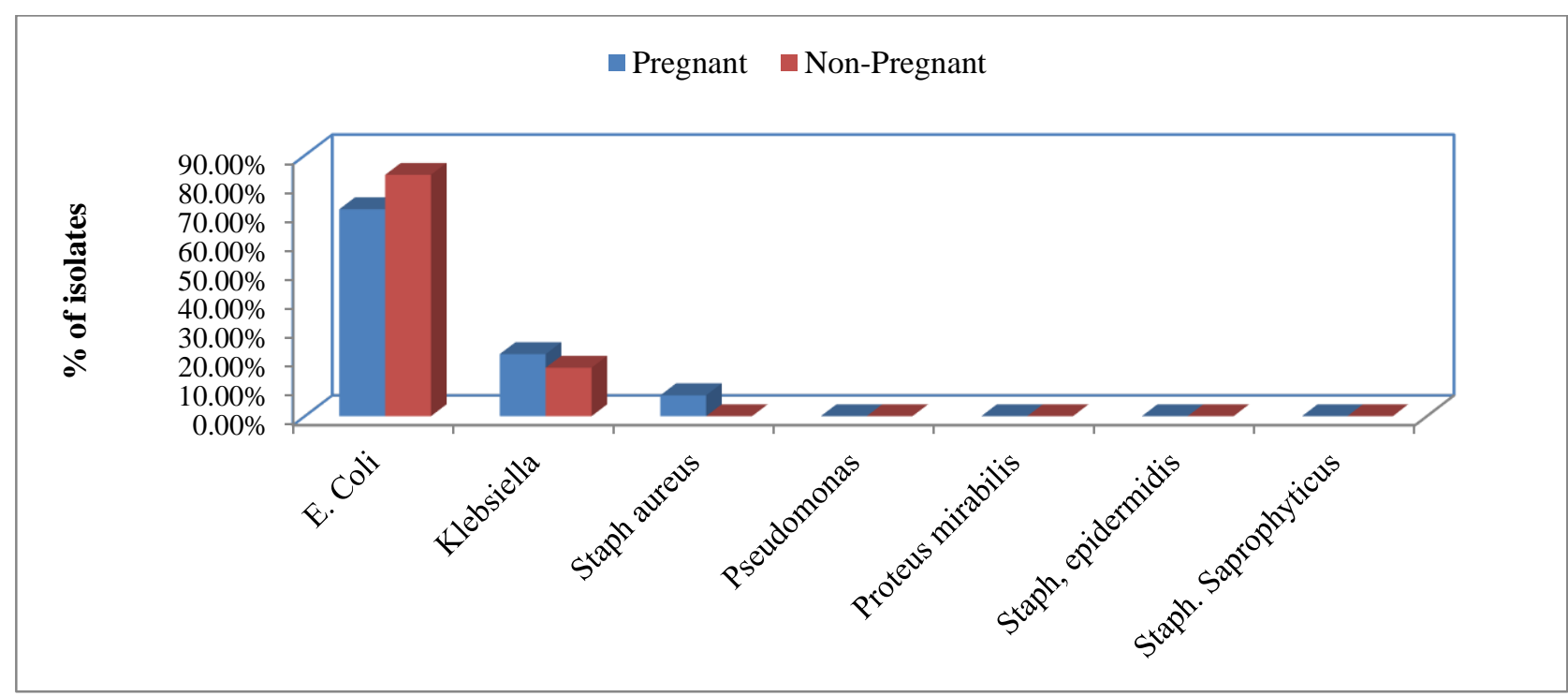

Most of isolates were got in the third trimester showing (64.3\%) of total isolates, and (21.4\%) in the second trimester and (14.3\%) in the first trimester of total isolates.

Table (2): Distribution of isolates in different trimesters

\begin{tabular}{|l|l|l|l|l|l|}
\hline & $\begin{array}{l}\text { Total numbers } \\
\text { of cases }\end{array}$ & $\begin{array}{l}\text { Number \& \% } \\
\text { of isolates }\end{array}$ & $\begin{array}{l}\text { Type of isolated } \\
\text { organism }\end{array}$ & $\begin{array}{l}\text { Prevalence } \\
\text { to specific } \\
\text { group }\end{array}$ & $\begin{array}{l}\text { P value } \\
\text { Significance } \\
\text { (P<0.05) }\end{array}$ \\
\hline Ist trimester & 31 & $2(14.3 \%)$ & $\begin{array}{l}\text { E Coli (1) } \\
\text { Klebsiella(1) }\end{array}$ & $0.4 \%$ & 064 \\
\hline $2^{\text {nd }}$ trimester & 35 & $3(21.4 \%)$ & $\begin{array}{l}\text { E Coli (2) } \\
\text { Klebsiella(1) }\end{array}$ & $8.5 \%$ & 0.055 \\
\hline $\mathbf{3}^{\text {rd }}$ trimester & 34 & $9(64.3 \%)$ & $\begin{array}{l}\text { E Coli (7) } \\
\text { Klebsiella(1) staph (1) }\end{array}$ & $26.4 \%$ & 0.034 \\
\hline
\end{tabular}

It was observed that the higher the literacy level, the lower the incidence of bacteriuria as those with tertiary education had low prevalence of asymptomatic bacteriuria than those with secondary and primary education. There were no statistically differences between infected and non-infected women in both groups (pregnant and non-pregnant) as regard the age, HB concentration, WBCs count, CRP and ESR.

The antibiotic susceptibility patterns of the isolates was determined. This was shown in table (3). Amoxicillin/clavulanic acid has the highest sensitivity to the isolated organisms during pregnancy (80\%), followed by cephalexin, nitrofurantoin and sulphanamides. In the other hand the antibiotics susceptibility of isolates in nonpregnant women showing that amikin and meropenem having the highly sensitivity to the isolates (100\%), followed by amoxicillin/clavulanic acid and nitrofurantoin, while sulphanamides, levofloxacin and ciprofloxacin showing the least sensitivity to the isolates. Urine analysis and urine culture and sensitivity test that was performed pre and post 5 days course of antibiotic treatment and after one month from the treatment showing no recurrence with no development of pyelonephritis in both groups (pregnant and nonpregnant women).

Table (3) Antibiotics susceptibility pattern of the isolates

\begin{tabular}{|c|c|c|c|c|c|}
\hline \multirow{2}{*}{$\begin{array}{l}\text { Antibiotics } \\
\text { No of samples }\end{array}$} & \multicolumn{3}{|l|}{ Pregnant } & \multicolumn{2}{|c|}{ Non-Pregnant } \\
\hline & $\begin{array}{l}\text { E coli } \\
(10 / 14)\end{array}$ & $\begin{array}{l}\text { Klebsiella } \\
(3 / 14)\end{array}$ & $\begin{array}{l}\text { Staph aureus } \\
(1 / 14)\end{array}$ & $\begin{array}{ll}\text { E } & \text { coli } \\
(5 / 6) & \end{array}$ & $\begin{array}{l}\text { Klebsiella } \\
(1 / 6)\end{array}$ \\
\hline Amoxicillin/clavulanic & $9 / 10(80 \%)$ & $2 / 3(66 \%)$ & $1 / 1(100 \%)$ & $4 / 5(80 \%)$ & 0 \\
\hline Cephalexin & $7 / 10(70 \%)$ & $1 / 3(33 \%)$ & $1 / 1(100 \%)$ & & \\
\hline Nitrofurantoin & $6 / 10(60 \%)$ & $1 / 3(33 \%)$ & $0 / 1(0 \%)$ & $3 / 5(60 \%)$ & $1 / 1(100 \%)$ \\
\hline Sulphonamides & $5 / 10(50 \%)$ & $0 / 3(0 \%)$ & $0 / 1(0 \%)$ & $2 / 5(40 \%)$ & 0 \\
\hline Amikin & & & & $5 / 5(100 \%)$ & $1 / 1(100 \%)$ \\
\hline Levofloxacin & & & & $2 / 5(40 \%)$ & 0 \\
\hline Ciprofloxacin & & & & $2 / 4(40 \%)$ & 0 \\
\hline Meropenem & & & & $5 / 5(100 \%)$ & $1 / 1(100 \%)$ \\
\hline
\end{tabular}




\section{DISCUSSION}

Urinary tract infections are relatively common problem during pregnancy. The physiologic changes related to pregnancy make healthy women susceptible to serious infectious complications, arising from conditions such as asymptomatic and symptomatic urinary tract infections. This includes dilatation of the ureter, decrease in ureteral peristalsis and decrease in bladder tone. Additionally, the physiologic increase in plasma volume during pregnancy, decreases urine concentration and increases urinary progestin and estrogens, which may lead to a decreased ability of the lower urinary tract to resist invading bacteria ${ }^{(7)}$.

The traditional definition of asymptomatic bacteriuria is the presence of 100,000 colony forming units per $\mathrm{ml}$ of urine of a single pathogen in two consecutive mid-stream, clean catch urine specimens or one catheterization specimen from an individual without symptoms of urinary tract infection ${ }^{(8)}$.

The prevalence of asymptomatic bacteriuria in this study was $14 \%$ among pregnant and $12 \%$ among non-pregnant women, which is similar to $14 \%$ reported by okono and his team in 1989 at Oba Femi Awo lowo university teaching hospital ${ }^{(9)}$, but it is higher than $9.3 \%{ }^{(10)}$, and $10 \%$ in a study in Brazil involved 505 women[1], and it is lower than $15 \%$ reported in a similar study at university of Nigeria teaching hospital $(\mathrm{UNTH})^{(11)}$.

Escherichia coli was the most common pathogen $(71.4 \% \& 83 \%)$ in infected pregnant and nonpregnant women respectively, followed by Klebsiella $(21.4 \% \& 16.7 \%)$ in both groups and staph aureus $7.2 \%$ in infected pregnant women only. As a comparison with our study, similar findings have been reported by other researchers ${ }^{[12]} . E$. coli is the most common microorganism in the vaginal and rectal area and because of the anatomical and the functional changes that occur during pregnancy, the risk of acquiring UTI from E. coli is high $^{(12)}$. Tugrul et al, in his study in Turkey found that $77.8 \%$ of the positive samples were infected by E-coli ${ }^{(13)}$. On the other hand Akerele et al, found out that Staph. Aureus (29.8\%), E-coli (29.1\%) \& Klebsiella $(21.5 \%)$ were the commonest organisms (14). The difference in geographic location \& climate could be a possible reason for the difference in organism's prevalence due to different organisms' habitat.

Our study showing that the higher literacy level had the lower incidence of bacteriuria and conversely with $\mathrm{p}$ value(0.026) which agree with Khattak et al. $^{(15)}$ and differ with Kovavisarach et al. ${ }^{(16)}$ and Praveen et al. ${ }^{(17)}$. This may be as a result of poor knowledge and practice of personal hygiene in pregnancy.
In our study there was no relation between the prevalence of ASB and maternal age although Akinloye et al. showed that with increase maternal age the prevalence of ASB also increased ${ }^{(18)}$, this may be due to in our study maternal age did not exceed 30 years and all cases were primipara.

Kovavisarac et al. reported that there was no significant difference in the prevalence of asymptomatic bacteriuria with respect to trimester ${ }^{(16)}$. But our study showing that third trimester has the highest prevalence of asymptomatic bacteriuria $64.3 \%$ $(\mathrm{p}=0.034)$ that agree with Akinloye et al. ${ }^{(18)}$ which may relate to the pressure effect of a much bigger uterus on the ureters, the increasing smooth muscle relaxing effect of pregnancy hormones and the pressure on the bladder from the descending presenting part, may all lead to stasis of urine which will encourage bacterial multiplication. Furthermore, the immunosuppressive effect of pregnancy may be most pronounced in third trimester.

The antibiotic sensitivity patterns showing that most of the bacterial isolates were sensitive to Amoxclav $(85 \%)$, cephalexin $(64 \%)$, nitrofurantoin $(50 \%)$ and sulphanamides $(35 \%)$ in pregnant, and Amikin, Levofloxacin in non- pregnant women. As a comparison with the study done by Abdullah \& AIMosleh, which concluded that the most sensitive antibiotic was gentamycin \& Augmentin ${ }^{(19)}$.Akerele et al, found that the most prevalent antimicrobial was Augmentin (71.4 \%), ceftazedime (81.6\%), nitrofurantoin $(61 \%)$ and gentamycin $(56.9 \%)^{[14]}$. The choice of antibiotic should be based on urine culture, stage of gestation, maternal clinical data and the characteristics of the antibiotic ${ }^{(20)}$.

Aggressive antibiotic treatment may be necessary to reduce the risk of pyelonephritis in pregnancy ${ }^{(21-22)}$. Ampicillin was the first line antibiotic for empirical treatment of urinary tract infection in pregnancy because of its safety, availability and low cost ${ }^{(23)}$. However the uncontrolled, frequent use, miss use of Ampicillin in Nigeria is likely to have contributed to the emergence of widespread resistance to the $\operatorname{drug}^{(24)}$.

Regarding the efficacy of treatment in our study was found that the five days course were effective in treatment of asymptomatic bacteriuria, with complete cure and no recurrence after one month.

Our results showed that anemia was not found to be a risk factor to asymptomatic bacteriuria, a nonsignificant statistical difference was noted regarding prevalence of ASB in anemic and non-anemic women $(\mathrm{p}<0.684) \&(\mathrm{p}<0.531)$ in pregnant and non-pregnant respectively. There is no agreement in comparison with Isabel et al, who studied the association of anemia and asymptomatic bacteriuria in their study, low 
hemoglobin levels were shown to be risk factors on univariate analysis ${ }^{(7)}$. However, on logistic regression analysis, the hemoglobin levels $<10.5 \mathrm{~g} \%$ was found to be independently associated with asymptomatic bacteriuria. Anemia was not found to be a risk factor in the study of Fatima and Ishrat ${ }^{(25)}$. Same result was observed in another study, conducted by Qureshi et $a .^{(26)}$.

\section{CONCLUSION}

UTIs during pregnancy are a common cause of serious maternal and perinatal morbidity, with appropriate screening and treatment, this morbidity can be limited, UTI may manifest as asymptomatic bacteriuria, acute cystitis or pyelonephritis. All pregnant women should be screened for bacteriuria and subsequently treated with appropriate antibiotic therapy. Acute cystitis and pyelonephritis should be aggressively treated during pregnancy. Oral nitrofurantoin and cephalexin are good antibiotic choices for treatment in pregnant women with asymptomatic bacteriuria and acute cystitis, but parental antibiotic therapy may be required in women with pyelonephritis.

\section{REFERENCES}

1.Enayat K, Fariba F, Bahram N (2008): Asymptomatic bacteriuria among pregnant women referred to outpatient clinics in Sanandaj, Iran, Int Braz. J Uro.,34(6):699-707.

2.Jayalakshmi J, Jayaram VS(2008): Evaluation of various screening tests to detect asymptomatic bacteriuria in pregnant women. Indian $\mathbf{J}$ Pathol Microbiol ., 51(3):379-381.

3.Kacmaz B, Cakir O, Aksoy A et al. (2006): Evaluation of rapid urine screening tests to detect asymptomatic bacteriuria in pregnancy. Jpn J Infect Dis., 59 (4):261263.

4.Gayathree L, Shetty S, Deshpande SR et al. (2010): Screening for asymptomatic bacteriuria in pregnancy: An evaluation of various screening tests in Hassan District Hospital, India. JCDR., 4 (4):2702-2706.

5. Patterson TF, Andriole VT (1997): Detection, significance and therapy of bacteriuria in pregnancy. Infect Dis ClinN Am.,11:593-608.

6. Shaifali l, Gupta U, Mahmood SE (2012): Antibiotic susceptibility patterns of urinary pathogens in females outpatients. N Am J Med Sci., 4: 163-9.

7. Isabel NC, Garingalao-Molina FD, Ycasiano CE et al. (2003): Prevalence of Asymptomatic Bacteriuria and Associated Risk Factors in Pregnant Women. Phil J Microbiol Infect Dis., 32(2): 63-9.

8. Kiningham Ro (1993): Asymptomatic bacteriuria in pregnancy. Am Fam Physician, 47(5): 1232-38.

9. Okono Fua FF, Adediran A, Okono F (1989): Incidence and pattern of asymptomatic bacteriuria of pregnancy in Nigeria women. Nig. Med. Pract.,17(3)3538.

10. Uncu Y, UncuG, Esrner A et al. (2002): Should asymptomatic bacteriuria be screened in pregnancy? Ciin Exp Obstet Gyr. Ecol., 29(4): 281-5.

11. Ezeome IV, Ikeme AC, Okezie OA, Onyebueke EA (2006): Asymptomatic bacteriuria (ASB) in pregnant women in Enugu, Nigeria. Tropical Journal of Obstetrics and Gynaecology, 23(1):12-3.

12. Mohammad M, Mahdy ZA, Omar J et al. (2002): Laboratory aspects of asymptomatic bacteriuria in pregnancy. Southeast Asian J Trop Med Public Health, 33(3): 575-80.

13. Tugrul S, Oral O, Kuniru $P$ et al. (2005): Evaluation and importance of asymptomatic bacteriuria in pregnancy. ClinFxpObstet Gynecol.,32(4): 237-40.

14. Akerele J, Abhldimen P, Okonofua F (2001): Prevalence of asymptomatic bacteriuria among pregnant women in Benin city, Nigeria. J ObstetGynaecol., 21: 141-4.

15. Kattak AM, khan HU, Mashud IU et al. (2006): Antimicrobial sensitivity pattern of urine isolates from asymptomatic bacteriuria during pregnancy. Biomedica ,22:67-70.

16. Kovavisarach E, Vichaipruck $M$, Kanjarahareutai $S$ et al. (2009): Risk factors related to asymptomatic bacteriuria in pregnancy, 92(5):606-10.

17. Praveen R, Saha SK, Shamshuzzaman SM et al. (2011): Detection of uropathogen by using chromogenic media (Hicrome UTI agar), CLED agar and other conventional media. Faridpur Med Coll. J., 6(1): 46-50.

18. Akinioye O, Ogbolu DO, Akinloye OM et al. (2006): Asymptomatic bacteriuria of pregnancy in Ibadan, Nigeria: a re-assessment. Br J Bioraed Sci., 63(3): 10912.

19. Abdullah A, Al-Mosleh M (2005): Prevalence of asymptomatic bacteriuria in pregnant women in Sharjah, United Arab Emirates. East Mediter Health J., 11(5-6): 1045-52.

20. Grio R (1994): Asymptomatic bacteriuria in pregnancy: a diagnostic and therapeutic approach. Panrninervamedica., 36: 195-7.

21. Smaill F (2001): Antibiotics for asymptomatic bacteriuria during pregnancy. Cochrane Database: Syst Rev.,2: 1-22.

22. Gratacos E et al. (1994): Screening and treatment of asymptomatic bacteriuria in pregnancy prevent pyelonephritis. J infect dis., 169: 1390-2.

23. Smith GW, Brimful H C (1984): Urinary tract infection in pregnancy PGD. Africa, 6: 231-254.

24. Mandara MU, Shi Hu So (1999): Asymptomatic bacteriuria in Antenatal patients at ABVTH Zaria, Nigeria. Trop.d. Obstetric, gynaecol., 16(1):44-45.

25. Fatima N, Ishrat $\mathbf{S}$ (2006): Frequency and risk factors of asymptomatic bacteriuria during pregnancy. JCPSPVol., 16 (4): 273-275.

26. Qureshi R, Khan K, Parr O et al. (1994): Bacteriuria and pregnancy outcome: a prospective hospital based study in Pakistani women. JPMA., 44: 12-3. 